\title{
Re-emergence of bluetongue, African horse sickness, and other Orbivirus diseases
}

\author{
N. James MacLachlan ${ }^{1 *}$, Alan J. Guthrie ${ }^{2}$ \\ ${ }^{1}$ Department of Pathology, Microbiology and Immunology, School of Veterinary Medicine, \\ University of California, Davis, CA 95616, USA \\ ${ }^{2}$ Equine Research Centre, Faculty of Veterinary Science, University of Pretoria, Onderstepoort, \\ 0110, Republic of South Africa
}

(Received 3 November 2009; accepted 25 January 2010)

\begin{abstract}
Arthropod-transmitted viruses (Arboviruses) are important causes of disease in humans and animals, and it is proposed that climate change will increase the distribution and severity of arboviral diseases. Orbiviruses are the cause of important and apparently emerging arboviral diseases of livestock, including bluetongue virus (BTV), African horse sickness virus (AHSV), equine encephalosis virus (EEV), and epizootic hemorrhagic disease virus (EHDV) that are all transmitted by haematophagous Culicoides insects. Recent changes in the global distribution and nature of BTV infection have been especially dramatic, with spread of multiple serotypes of the virus throughout extensive portions of Europe and invasion of the south-eastern USA with previously exotic virus serotypes. Although climate change has been incriminated in the emergence of BTV infection of ungulates, the precise role of anthropogenic factors and the like is less certain. Similarly, although there have been somewhat less dramatic recent alterations in the distribution of EHDV, AHSV, and EEV, it is not yet clear what the future holds in terms of these diseases, nor of other potentially important but poorly characterized Orbiviruses such as Peruvian horse sickness virus.
\end{abstract}

Orbivirus / bluetongue / African horse sickness / Arbovirus emergence / climate change

\section{Table of contents}

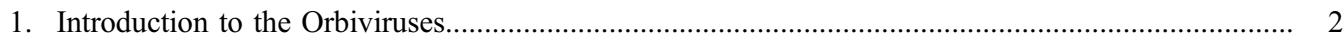

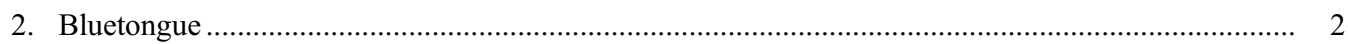

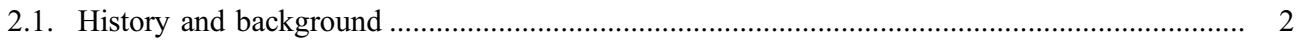

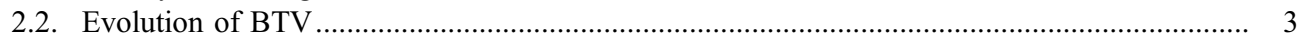

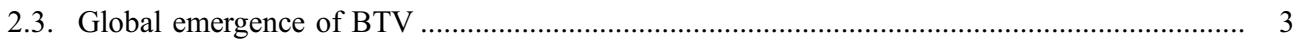

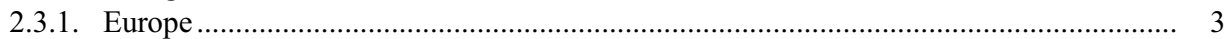

2.3.2. North America, Australia and the Middle East .......................................................... 4

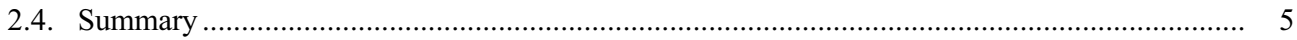

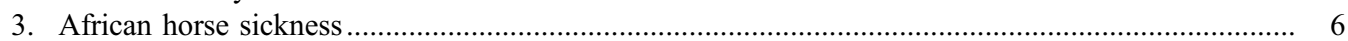

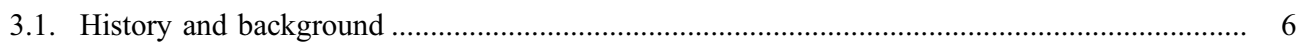

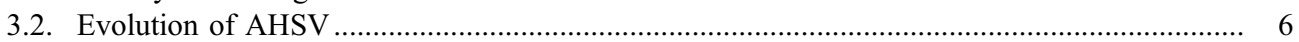

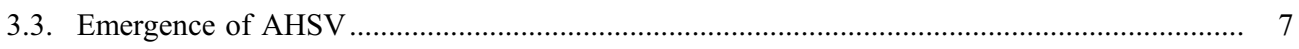

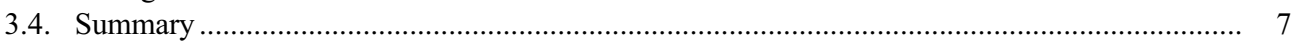

\footnotetext{
* Corresponding author: njmaclachlan@ucdavis.edu

This is an Open Access article distributed under the terms of the Creative Commons Attribution-Noncommercial License (http://creativecommons.org/licenses/by-nc/3.0/), which permits unrestricted use, distribution, and reproduction in any noncommercial medium, provided the original work is properly cited.
} 


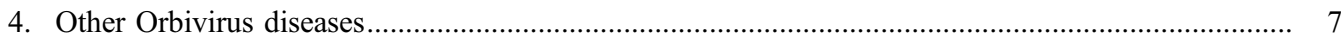

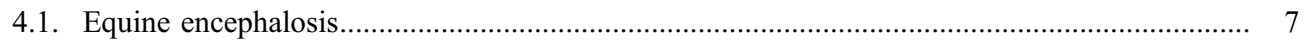

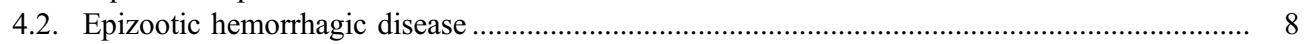

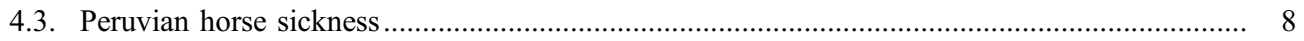

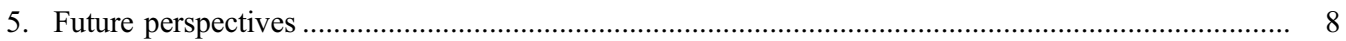

\section{INTRODUCTION TO THE ORBIVIRUSES}

Viruses within the genus Orbivirus, family Reoviridae, are characterized by icosahedral virions that include a genome of 10 distinct segments of linear double-stranded (ds) RNA $[33,56,63]$. Orbiviruses are transmitted to animals primarily by arthropod vectors, which, depending on the individual virus can be certain species of Culicoides midges, mosquitoes, black flies, sandflies, or ticks. The global and seasonal distribution of individual viruses coincides with that of their specific biological vector and appropriate climatic conditions. Bluetongue virus (BTV) and African horse sickness virus (AHSV) are the most economically important members of this genus, but several others are potentially important, either regionally or globally, including Equine encephalosis virus (EEV), Epizootic hemorrhagic disease virus (EHDV), Palyam virus, and Peruvian horse sickness virus (PHSV). With the notable exception of PHSV that is likely transmitted by mosquitoes, all of these viruses are transmitted by adult females of certain species of haematophagous Culicoides midges. The marked genetic and phenotypic diversity of BTV, AHSV, EHDV and EEV is reflected by the multiple serotypes that occur within each of these virus species, which can complicate diagnostic and vaccine strategies for their detection and prophylaxis $[20,48,54,84]$.

The recent emergence of multiple serotypes of BTV into much of Europe and portions of North America, the emergence of EEV and EHDV and novel strains of BTV in Israel, and the appearance of multiple serotypes of AHSV in sub-Saharan Africa, has fuelled concerns regarding the likely impact of climate change on the potential emergence of these diseases $[5,29,30,89]$. This concern is consistent with the premise that climate change will favour emergence of arthropod-transmitted diseases because it will promote expansion of the range of tropical insects and the agents they transmit $[34,35,53,68,74,85]$. However, the emergence or re-emergence of arthropod-transmitted diseases in general, and those caused by Orbiviruses in particular, is likely to be a highly complex process driven by a wide variety of potential factors $[11,58,65,66,75,91]$. Indeed, the recent spread of several arboviral diseases appears to have resulted not so much from the direct effects of climate change itself but from anthropogenic and social factors, and/or the movement (translocation) of virus-infected vectors or their hosts. The true role climate change in causing the recent global expansion of the range and distribution of BTV and other Orbiviruses, therefore, remains conjectural.

\section{BLUETONGUE}

\subsection{History and background}

Bluetongue (BT) is a non-contagious, insecttransmitted disease of ruminants, particularly sheep and certain species of non-African wild ruminants [57, 84]. The disease was first described in the Cape Colony of southern Africa after merino sheep were introduced into the region in the late 18th century, and was subsequently recognized in other parts of Africa, Europe, the Middle East and Indian subcontinent, the Americas, and Asia. Twenty-four (likely 25) serotypes of BTV are recognized globally [43], and the virus has now been isolated on all continents except Antarctica. The traditional global range of BTV has been considered to reside between latitudes of approximately $40-50^{\circ} \mathrm{N}$ and $35^{\circ} \mathrm{S}$; thus the northern limits previously were considered to be southern British Columbia in North America and 
Kazakhstan and Mongolia in Asia, and the southern limits in Africa, Australia and South America were, respectively, southern South Africa, northern New South Wales, and northern Argentina. The species of Culicoides insects that serve as the principal vectors of the virus differ between regions, as do the constellations of BTV serotypes and genetic strains (topotypes) that occur within each $[55,79]$.

BT is characterized by BTV-induced vascular injury that results in haemorrhage and ulceration of the mucous membranes in the upper portion of the gastrointestinal tract; coronitis and laminitis; facial and intermuscular oedema; pleural and pericardial effusion; pulmonary oedema; and necrosis of skeletal and cardiac muscle [57, 77, 84]. BT was infrequently described in cattle prior to emergence of BTV serotype 8 in Europe, however sheep, cattle, goats, camelids (llamas, alpacas), bison, yaks, deer and even zoo carnivores such as Eurasian lynx have all been affected during this ongoing pandemic [21, 27, 50, 57, 59]. In addition to causing clinical disease in domestic and wild ungulates, BTV serotype 8 infections has caused reproductive failure amongst pregnant cattle and sheep and a high rate of vertical virus transmission with teratogenic defects in congenitally infected calves [24, 87, 88].

BTV infection of ruminants results in prolonged, but not persistent cell associated viraemia [57]. Highly sensitive and specific serological (competitive ELISA) and virus detection (quantitative PCR) assays are now widely available to confirm the presence or absence of BTV infection in animals [42]. Furthermore, infection with one BTV serotype confers long-term (likely life-long) immunity to the homologous serotype. Thus, livestock can safely be moved into BTV-free regions regardless of the status of the exporting region, but only with stringent adherence to appropriate testing and quarantine practices as prescribed by the World Organisation for Animal Health (OIE) [6].

\subsection{Evolution of BTV}

There is extensive genetic heterogeneity of field strains of BTV, and this genetic variation is likely responsible for differences in the virulence and other biological properties of individual field strains of the virus. This diversity arises as a consequence of both genetic shift and genetic drift, the latter as a result of reassortment of viral genes during mixed infections of either the vertebrate or invertebrate hosts following infection with more than one virus serotype or strain [17]. Variation in the nucleotide sequence of each of the 10 dsRNA segments of the BTV genome occurs as a result of the complex process of quasispecies evolution and founder effect during alternating passage of BTV in its ruminant and insect hosts [16]. Furthermore, negative (purifying) selection of individual BTV genes occurs over time following the incursion of novel viruses into new regions, creating genetically distinct region-specific clusters (topotypes) of certain virus genes $[9,15]$. Genetic differences are responsible for clearly documented differences in phenotypic properties (such as virulence) of BTV strains, even of the same serotype, and can complicate the design and use of nucleic acid based virus detection methods such as reverse transcriptase polymerase chain reaction (RT-PCR) assays. The genetic determinants of BTV virulence remain uncharacterized, however, as do those that presumably are responsible for, or associated with, emergence of the virus in new regions and in novel vector species.

\subsection{Global emergence of BTV}

The global distribution and nature of BTV infection has changed significantly in recent years, and climate change has been implicated as a potential cause of this dramatic event, especially in Europe [29, 69, 70].

\subsubsection{Europe}

Until recently, only transient incursions of single serotypes of BTV had occurred in Europe but, since 1998, at least 8 different serotypes of BTV have emerged and persisted in Europe causing substantial economic losses through mortality and reduced productivity of affected animals, the requirement for mass vaccination of susceptible livestock, and restrictions on the 
movement and trade of animals from affected regions [86]. A current distribution map of restriction zones for individual BTV serotypes within Europe is available at http://ec.europa.eu/food/animal/diseases/controlmeasures/ bt_restrictedzones-map.jpg. Five BTV serotypes $(1,2,4,9$ and 16) initially invaded the Mediterranean basin by extension from adjacent regions of either North Africa or the Middle East ${ }^{1}$. Although these 5 serotypes have persisted in extensive portions of the Mediterranean basin, only BTV serotype 1 has since spread to northern Europe. Subsequent to the spread of BTV serotypes 1, 2, 4, 9 and 16 within the Mediterranean basin, BTV serotypes 6, 8 and 11 all appeared in northern Europe (Benelux) after 2006; whereas the strains of BTV serotypes 6 and 11 are closely related to South African live attenuated vaccine viruses $^{1}$ [25], the origin of the highly pathogenic strain of BTV serotype 8 that has now spread throughout much of Europe remains unknown. Since its appearance in northern Europe, this virus has now spread to the Mediterranean basin, Scandinavia, and the Middle East. This strain of BTV serotype 8 exhibits several distinctive features that are unusual amongst other field strains of BTV, notably its ability to cross the ruminant placenta with high frequency [88]. Vertical transmission has previously been considered to be largely or exclusively a property of BTV strains modified by growth in embryonated eggs or cell culture [57].

An additional remarkable feature of the BT pandemic in Europe is the recognition of several apparently new vector species, including Palaearctic species such as Culicoides chiopterus, C. dewulffi, C. obsoletus, C. scotius, and C. pulicaris [86]. These insects were all resident in Europe long before the emergence of multiple serotypes of BTV, suggesting that environmental changes may have been responsible for their recent ability to serve as efficient vectors of the virus $[69,70]$. While it is proposed that recent environmental changes have facili-

\footnotetext{
${ }^{1}$ Mertens P.P.C., Maan S., Potgieter A.C., Nomikou K., Maan N.S., The molecular epidemiology of bluetongue virus infection in Europe: impact of vaccination, Proc. Ann. Mtg. US Anim. Health Assoc. (2009) (in press).
}

tated expansion of the range of known vectors such as Culicoides imicola, the traditional Asian/African vector, this opinion is strongly disputed by others. Importantly, several of the Palaearctic Culicoides species that are now efficiently transmitting BTV in the absence of known vectors such as $C$. imicola, also occur throughout the Holarctic region that includes North America [18]. This raises the unnerving possibility that the viruses that have recently spread throughout extensive portions of Europe, especially the unusual and highly virulent strain of BTV serotype 8 , might even further expand their global range in the future.

\subsubsection{North America, Australia and the Middle East}

Five BTV serotypes have long been recognized as enzootic in North America, specifically serotypes 10,11, 13 and 17 occur throughout much of the continent coincident with the distribution of $C$. sonorensis, whereas serotype 2 is restricted to the south-eastern USA apparently because of its reliance on $C$. insignis for transmission $[55,79]$. Since 1998 ten additional previously exotic serotypes $(1,3,5,6,9,12,14$, $19,22,24)$ have also been isolated in the south-eastern USA, but without any obvious associated disease outbreak ${ }^{2}$. The majority (but not all) of these virus serotypes were previously identified in the Caribbean/Central America ecosystem, as determined by either virus isolation or serological studies on ruminants in the region [79]. Thus, the BTV serotypes that recently have encroached into the south-eastern USA have likely originated in the adjacent tropical ecosystem to the immediate south, where $C$. insignis and possibly other species such as $C$. pusillus, $C$. furens, $C$. filarifer and $C$. trilineatus are the vectors of numerous BTV serotypes [58]. The importance of vector species other than $C$. sonorensis is largely undetermined in North America, and there has been little or no comprehensive, prospective surveillance of the viruses and vectors present

\footnotetext{
${ }^{2}$ Ostlund E.N., NVSL update to the bluetongue and related Orbiviruses Committee, Proc. Ann. Mtg. US Anim. Health Assoc. (2009) (in press).
} 
in the USA and Caribbean basin/Central America for several decades.

Additional novel serotypes of BTV have also recently invaded Israel and Australia, countries that previously had stable annual cycles of BTV infection (virus serotypes and distribution), as shown by ongoing surveillance over many years. Specifically, BTV serotypes 2, 4, 6, 10, 16 previously were recognized in Israel, but serotypes 5, 8, 15 and 24 have all recently emerged in the country and the occurrence of serotype 24 in particular was associated with very high mortality in infected sheep. Interestingly, BTV serotype 24 also recently appeared in the southeastern USA without any associated disease outbreak, further confirming that serotype alone does not determine the virulence of individual field strains of BTV [57]. Similarly, 8 serotypes $(1,3,9,15,16,20,21,23)$ of BTV previously have been identified in Australia, of which only two (serotypes 1 and 21) annually spread into eastern Australia as far south as northern New South Wales; however, BTV serotypes 2 and 7 were recently identified for the first time in the Northern Territory of Australia. Finally, BTV infection is enzootic in the Indian subcontinent with the presence of at least 21 serotypes of the virus, however there are multiple recent, largely unexplained, reports of the emergence of virulent BT disease amongst indigenous breeds of sheep.

\subsection{Summary}

The essential question remains as to why BTV has recently emerged in previously unaffected regions, and why exotic virus serotypes have spread into regions with previously stable enzootic infection with specific virus serotypes. In the south-eastern USA, northern Australia, and southern Europe, it is very likely that most if not all of these novel, emergent BTV serotypes have originated and spread from adjacent tropical or subtropical ecosystems. It is to be stressed that subsequent virus transmission within these newly affected regions clearly requires the presence of competent resident Culicoides vectors, which in several recent instances involves virus transmission by indigenous insect species that previously were not considered to be competent vectors of BTV.
Climate events such as storms, typhoons and hurricanes have been frequently proposed to be responsible for the wind-borne dissemination of virus-infected Culicoides midges, but longdistance dissemination of virus-infected insects likely can occur simply on prevailing winds. For instance, there is compelling evidence that BTV serotype 8 was spread in 2007 from continental Europe to adjacent regions of England by wind-borne insects, after which there was limited regional dissemination by resident insects [32]. Wind-borne insects are believed to have also been responsible for the recent spread of BTV from North Africa to southern Europe, and between Mediterranean islands, in some instances involving distances of up to several hundred kilometres. It has even been proposed that serotypes of BTV that occur in Africa can be spread to the Americas by virus-infected insects carried on the trade winds [31], a finding that is consistent with genetic topotyping studies of global BTV strains. Specifically, genetic analysis of conserved genes of BTV strains from the around the world segregates these viruses into so-called "eastern" (Asia, Southeast Asia, Australia, Indian subcontinent) and "western" (Africa, the Americas) lineages, consistent with common ancestry of the viruses in each lineage ${ }^{1}[9,15]$.

In contrast, both the route of introduction and origin of the strain of BTV serotype 8 that recently invaded northern Europe are uncertain, and this event very clearly represents a longdistance translocation of BTV into a region devoid of $C$. imicola, the principal African/ Asian vector of BTV. The strain of BTV serotype 8 is unrelated to the South African live attenuated vaccine virus of that serotype whereas the strains of BTV serotypes 6 and 11 that recently appeared in northern Europe are apparently derived at least in part from South African live attenuated vaccine viruses ${ }^{1}$ [25], although their precise route and mechanism of introduction also remains a mystery. The very disconcerting message from these recent events to the rest of the world, therefore, is that exotic strains of BTV can be translocated into previously free regions, including those devoid of known vector species but in which other putatively "non vector" Culicoides 
species are resident. Furthermore, the remarkable expansion of BTV serotype 8 into northern Europe and Scandinavia indicates that climate no longer can be relied on to confine BTV to its traditional global range between $40-50^{\circ} \mathrm{N}$ and $35^{\circ} \mathrm{S}$. It is difficult to predict therefore, what the global range and distribution of BTV will become in coming years.

\section{AFRICAN HORSE SICKNESS}

\subsection{History and background}

African horse sickness (AHS) is a non-contagious, insect-transmitted disease of equids caused by AHSV. In horses, the disease is usually peracute to acute and in naive animals more than $90 \%$ of those affected die. Mules are less susceptible than horses and African donkeys and zebras rarely show clinical signs of disease [36, 37]. The first known historical reference to a disease resembling AHS was reported in Yemen in 1327 [41]. Documents reporting on the travels of Portuguese explorers in East Africa in 1569 report AHS affecting horses imported from India [41]. Neither horses nor donkeys were indigenous to southern Africa but were introduced shortly after the arrival of the first settlers of the Dutch East India Company in the Cape of Good Hope in 1652 [83]. Dutch East India Company records make frequent reference to "perreziekte" or "pardeziekte" in the Cape of Good Hope [83] including an outbreak in 1719 during which about 1700 horses died of AHS. AHS has subsequently been recognized in other parts of subSaharan Africa where AHSV is considered to be enzootic.

Nine serotypes of AHSV are recognized $[45,61]$. Like BTV, AHSV is biologically transmitted by Culicoides spp., of which $C$. imicola and $C$. bolitinos have been shown to play an important role in Africa [62]. The disease has a seasonal occurrence and its prevalence is influenced by climatic and other conditions that favour the breeding of Culicoides spp. Although other insects have been suggested as possible vectors of AHSV, none have been shown to play a role under natural conditions. AHSV can be transmitted between horses by parenteral inocu- lation of infective blood or organ suspensions and it is more readily transmitted by the intravenous than by the subcutaneous route [82].

AHS is characterized by pyrexia, inappetence and clinical signs and lesions compatible with impaired respiratory and vascular functions with oedema of subcutaneous and intermuscular tissues and of the lungs, transudation into the body cavities, and haemorrhages, particularly of the serosal surfaces. Dogs are the only other species that contract a highly fatal form of AHS $[39,80]$. All reported clinical cases in dogs have resulted from the ingestion of infected carcass material from horses that have died from AHS [12, 67]. However, it is doubtful that dogs play any role in the epidemiology of AHS, as Culicoides spp. do not readily feed on them [60]. Neither domestic ruminants nor wildlife, besides zebra [10, 13, 22, 28], have been shown to play a significant role in the epidemiology of AHS. In contrast to some strains of BTV, especially the European strain of BTV serotype 8, AHSV infection does not cause reproductive failure amongst pregnant equids.

AHSV infection of equids results in a cell associated, predominantly erythrocyte associated viraemia of up to 28 days in horses and up to 40 days in zebra. Highly sensitive and specific virus detection (quantitative PCR) assays are now more widely available to confirm the presence or absence of AHSV infection in equids. Thus, horses can safely be moved into AHSV-free regions regardless of the status of the exporting region, but only with stringent adherence to appropriate testing and quarantine practices as prescribed by OIE [7].

\subsection{Evolution of AHSV}

Like BTV, there is extensive genetic heterogeneity of field strains of AHSV that potentially determines the biological behaviour and properties of individual virus strains, including their virulence [19]. This genetic diversity also likely arises as a consequence of both genetic shift and genetic drift, the latter as a result of reassortment of viral genes and the former through quasispecies evolution of the virus in its vertebrate host followed by founder effect in feeding insects that results in variation in the nucleotide 
sequence of each of the 10 dsRNA segments of the AHSV genome. Like those of field strains of BTV, individual AHSV gene segments further evolve over time through negative (purifying) selection [71]. The genetic determinants of AHSV virulence remain uncharacterized, as do those that might determine whether or not the virus can emerge in novel vector species.

\subsection{Emergence of AHSV}

Nine antigenically distinct serotypes of AHSV have been described [45, 61]. While there may be some cross relatedness between the serotypes there is no definitive evidence of any intratypic variation [45, 61]. All 9 serotypes have been documented in eastern [23] and southern Africa [14, 45, 61] while serotype 9 is more widespread and appears to predominate in the northern parts of sub-Saharan Africa $[1,76]$. AHS has been periodically recorded beyond its traditional enzootic range in subSaharan Africa, including in Egypt in 1928, 1943, 1953, 1958 and 1971 [37], in Yemen in 1930 and in Palestine, Syria, Lebanon and Jordan in 1944 [2]. In 1959, AHS serotype 9 occurred in the south-eastern portion of Iran. This was followed by outbreaks during 1960 in Cyprus, Iraq, Syria, Lebanon and Jordan as well as in Afghanistan, Pakistan, India and Turkey. Between 1959 and 1961, more than 300000 equids were lost to AHS [44, 46, 72]. In 1965 AHS occurred in Libya, Tunisia, Algeria and Morocco and subsequently spread to Spain in 1966 [40]. Between 1987 and 1990, AHS serotype 4 occurred in Spain with the virus being introduced by zebra (Equus burchelli) imported from Namibia [52, 73]. AHS was also confirmed in southern Portugal in 1989 and Morocco between 1989 and 1991 with these outbreaks being extensions of the outbreak in Spain [92]. In 1989, an outbreak of AHS serotype 9 occurred in Saudi Arabia [4]. AHS was also reported in Saudi Arabia and Yemen in 1997 and on the Cape Verde Islands in 1999. Serotypes 6 and 9 of AHSV were isolated from samples collected from equids in Ethiopia in 2003 [90] and serotype 2 has resulted in the death of approximately 2000 horses in Ethiopia in 2008. Serotypes 2 and 7 of AHSV were isolated in Senegal in 2007 and serotype 2 was isolated in Nigeria in 2007. AHS was also reported in The Gambia in 2007. AHSV can be distributed over great distances if equids incubating the disease are translocated by land, sea or air $[52,73]$. Spread of AHS can also occur as a result of wind-borne spread of infected vectors [78].

\subsection{Summary}

There have been numerous documented prior extensions of AHSV from its enzootic domain within sub-Saharan Africa into North Africa, Europe and the Middle and Near East. The only recorded introduction of AHS from an enzootic to a free region that occurred as the result of legal trade in equids was the outbreak on the Iberian Peninsula in the 1980s, which was associated with import of zebra from Namibia without application of appropriate sanitary conditions. The European Union has now harmonized import conditions and other veterinary administrations are acutely aware of risks associated with import of exotic species and therefore a reoccurrence is unlikely.

All 9 serotypes of AHSV occur in eastern and southern Africa, however there recently has been an increase in the number of serotypes present within the northern limits of the virus' range in sub-Saharan Africa. This spread of at least 3 different serotypes into these areas is disconcerting because recent experiences with BTV indicate that once these viruses reach North Africa they readily can spread throughout the Mediterranean basin. The incursion of AHSV into countries of Europe or the Middle East that are extensively involved in the international trade and movement of horses would be economically devastating, thus there is substantial current concern regarding potential spread of AHS from Africa into adjacent regions [26, 29].

\section{OTHER ORBIVIRUS DISEASES}

\subsection{Equine encephalosis}

Equine encephalosis (EE) is usually a mild or subclinical Orbivirus infection of horses 
[38]. The virus is transmitted by species of Culicoides that are endemic to the temperate regions of Africa and, as a result, the epidemiology of EEV infection has much in common with AHS. The disease referred to as "equine ephemeral fever" by Sir Arnold Theiler in the early 1900s [81] is probably the first description of EE. Fatal EEV infection can occur, but rarely $[47,49]$. EEV has long been enzootic in of Africa but was described recently for the first time in Israel [64]. The Israeli outbreak was widespread and infected horses exhibited pyrexia, oedema of the neck, legs, eyelids and lips, but without mortality. Similar clinical signs were also associated with a recent outbreak of EE in Thoroughbred weanlings in the Western Cape Province of South Africa ${ }^{3}$.

\subsection{Epizootic hemorrhagic disease}

EHDV is an Orbivirus closely related to BTV that occurs throughout much of the world, including the Americas, Africa, Australia and Asia [54]. Ibaraki virus (EHDV serotype 2), is the cause of Ibaraki disease of cattle in Japan [51]. Two EHDV serotypes (serotypes 1 and 2) have long been enzootic in North America, where they cause fatal hemorrhagic disease in wild ruminants, especially white-tailed deer. A third EHDV serotype (serotype 6) recently emerged in the USA, and this virus has now been isolated as far north as the state of Michigan [3]. Interestingly, EHDV serotype 6, which was originally isolated in Australia, also has emerged amongst cattle in North Africa and Turkey. Affected cattle in North Africa exhibited BT-like disease, as did cattle in Israel infected with EHDV serotype 7 [89].

\subsection{Peruvian horse sickness}

PHSV is a mosquito-transmitted Orbivirus that is the cause of outbreaks of encephalitis amongst horses in South America [8]. A very similar, likely identical virus, Elsey virus, is

\footnotetext{
${ }^{3}$ Grewar J.D., Use of temperature sensitive microchip transponders to monitor body temperature and pyrexia in Thoroughbred foals, MSc Dissertation, University of Pretoria, South Africa, 2009.
}

present in the Northern Territory of Australia where infection can cause encephalitis like that described with PHSV. The epidemiology of the infections caused by these viruses is poorly characterized, and it is uncertain how identical viruses came to be present in such distinct regions of the world.

\section{FUTURE PERSPECTIVES}

It is abundantly clear that the global distribution of several Culicoides-transmitted Orbivirus infections of livestock has altered drastically of late, although the precise mechanism(s) responsible for these events is less certain. Specifically, it is clear that the wind-borne dispersion of virusinfected Culicoides insects as "aerial plankton" can translocate these viruses over long distances, as can the movement of virus-infected livestock. Human interventions, including the intentional or unintentional introduction of products that contain Orbiviruses, also can result in longdistance translocation of these viruses as previously shown with the introduction of AHS into Spain through the importation of infected zebra and the translocation of BTV serotype 1 from south-eastern France to Brittany by illegal movement of livestock. Viruses that are transmitted vertically, notably the strain of BTV serotype 8 that recently has spread rapidly after its original incursion into northern Europe, can be expected to contaminate foetal tissues and fluids such as foetal bovine serum and so all such products from animals in enzootic regions are a potential source of virus.

Once Orbiviruses are translocated into new regions, subsequent virus dissemination requires that resident Culicoides are able to acquire and transmit the specific virus. The environmental (including climatic), virus and vector (insect) determinants that determine vectorial capacity are only now being defined, thus many current risk analyses are based on data that are of dubious relevance and validity. The reality is that several Orbiviruses recently have expanded their global range, and it is difficult to accurately predict which of the many species of Culicoides insects that occur worldwide ultimately will be proven to be vectors of these viruses. Until 
better predictive models are available it would be unwise for any country with resident populations of Culicoides insects, regardless of current status for Orbivirus infection, to assume that one or more of these viruses could not emerge at some time in the future. However, any such incursion can now be rapidly identified through appropriate surveillance utilizing sensitive and specific molecular diagnostic assays.

\section{REFERENCES}

[1] Adeyefa C.A., Hamblin C., Continuing prevalence of African horse sickness in Nigeria, Rev. Elev. Med. Vet. Pays Trop. (1995) 48:31-33.

[2] Alexander R.A., The 1944 epizootic of horsesickness in the Middle East, Onderstepoort J. Vet. Sci. Anim. Ind. (1948) 23:77-92.

[3] Allison A.B., Goekjian G.H., Potgieter C., Wilson W.C., Johnson D.J., Mertens P.P., Stallknecht D.E., Detection of a novel reassortant epizootic hemorrhagic disease virus in the USA containing RNA segments derived from both exotic (EHDV-6) and endemic (EHDV-2) serotypes, J. Gen. Virol. (2009) 91:430-439.

[4] Anderson E.C., Mellor P., Hamblin C., African horse sickness in Saudi Arabia, Vet. Rec. (1989) 125:489.

[5] Anonymous, OIE concern about climate change, Vet. Rec. (2009) 164:735.

[6] Anonymous, Bluetongue, Terrestrial Animal Health Code, Office International des Epizooties, Paris, 2009.

[7] Anonymous, African horse sickness, Terestrial Animal Health Code, Office International des Epizooties, Paris, 2009.

[8] Attoui H., Mendez-lopez M.R., Rao S., HurtadoAlendes A., Lizaraso-Caparo F., Jaafar F.M., et al., Peruvian horse sickness virus and Yunnan Orbivirus, isolated from vertebrates and mosquitoes in Peru and Australia, Virology (2009) 394:298-310.

[9] Balasuriya U.B.R., Nadler S.A., Wilson W.C., Pritchard L.I., Smythe A.B., Savini G., et al., The NS3 proteins of global strains of bluetongue virus evolve into regional topotypes through negative (purifying) selection, Vet. Microbiol. (2008) 126:91-100.

[10] Barnard B.J.H., Antibodies against some viruses of domestic animals in southern African wild animals, Onderstepoort J. Vet. Res. (1997) 64:95-110.

[11] Beebe N.W., Cooper R.D., Mottram P., Sweeney A.W., Australia's dengue risk driven by human adaptation to climate change, PLoS Negl. Trop. Dis. (2009) 3:e429.

[12] Bevan L.E.W., The transmission of African horsesickness to the dog by feeding, Vet. J. (1911) 67:402-408.

[13] Binepal V.S., Wariru B.N., Davies F.G., Soi R., Olubayo R., An attempt to define the host range for African horse sickness virus (Orbivirus, Reoviridae) in East Africa, by a serological survey in some Equidae, Camelidae, Loxodontidae and Carnivore, Vet. Microbiol. (1992) 31:19-23.

[14] Blackburn N.K., Swanepoel R., African horse sickness in Zimbabwe: 1972 to 1981, Trop. Anim. Health Prod. (1988) 20:169-176.

[15] Bonneau K.R., Zhang N., Zhu J., Zhang F., Li Z., Zhang K., et al., Sequence comparison of the L2 and S10 genes of bluetongue viruses from the United States and the People's Republic of China, Virus Res. (1999) 61:153-160.

[16] Bonneau K.R., Mullens B.A., MacLachlan N.J., Occurrence of genetic drift and founder effect during quasispecies evolution of the VP2 and NS3/NS3A genes of bluetongue virus upon passage between sheep, cattle, and Culicoides sonorensis, J. Virol. (2001) 75:8298-8305.

[17] Bonneau K.R., MacLachlan N.J., Genetic diversification of field strains of bluetongue virus, Vet. Ital. (2004) 40:446-447.

[18] Borkent A., Grogan W.L., Catalog of the New World biting midges north of Mexico (Diptera: Ceratopogonidae), Zootaxa (2009) 2273:1-48.

[19] Burrage T.G., Laegreid W.W., African horsesickness: pathogenesis and immunity, Comp. Immunol. Microbiol. Infect. Dis. (1994) 17:275-285.

[20] Coetzer J.A.W., Guthrie A.J., African horse sickness, in: Coetzer J.A.W., Tustin R.C. (Eds.), Infectious diseases of livestock, 2nd ed., Oxford University Press Southern Africa, Cape Town, 2004, pp. 1231-1246.

[21] Darpel K.E., Batten C.A., Veronesi E., Shaw A.E., Anthony S., Bachanek-Bankowska K., et al., Clinical signs and pathology shown by British sheep and cattle infected with bluetongue virus serotype 8 derived from the 2006 outbreak in northern Europe, Vet. Rec. (2007) 161:253-261.

[22] Davies F.G., Oteino S., Elephants and zebras as possible reservoir hosts for African horse sickness virus, Vet. Rec. (1977) 100:291-292.

[23] Davies F.G., Soi R.K., Binepal V.S., African horse sickness viruses isolated in Kenya, Vet. Rec. (1993) 132:440.

[24] De Clercq K., De Leeuw I., Verheyden B., Vandemeulebroucke E., Vanbinst T., Herr C., et al., 
Transplacental infection and apparently immunotolerance induced by a wild-type bluetongue virus serotype 8 natural infection, Transbound. Emerg. Dis. (2008) 55:352-359.

[25] De Clercq K., Mertens P.P., De Leeuw I., Oura C.A., Houdart P., Potgieter A.C., et al., Emergence of bluetongue serotypes in Europe, Part 2: the occurrence of a BTV-11 strain in Belgium, Transbound. Emerg. Dis. (2009) 56:355-361.

[26] Dufour B., Moutou F., Hattenberger A.M., Rodhain F., Global change: impact, management risk approach and health measures - the case of Europe, Rev. Sci. Tech. (2008) 27:529-550.

[27] Elbers A.R., Backx A., Meroc E., Gerbier G., Staubach C., Hendrickx G., et al., Field observations during the bluetongue serotype 8 epidemic in 2006. I. Detection of first outbreaks and clinical signs in sheep and cattle in Belgium, France and the Netherlands, Prev. Vet. Med. (2008) 87:21-30.

[28] Erasmus B.J., Young E., Pieterse L.M., Boshoff S.T., The susceptibility of zebra and elephants to African horsesickness virus, in: Bryans J.T., Gerber H. (Eds.), Equine infectious diseases IV, Veterinary Publications Inc., Princeton, New Jersey, 1978, pp. 409-413.

[29] Gale P., Brouwer A., Ramnial V., Kelly L., Kosmider R., Fooks A.R., Snary E.L., Assessing the impact of climate change on vector-borne viruses in the EU through the elicitation of expert opinion, Epidemiol. Infect. (2009) 7:1-12.

[30] George J.E., The effects of global change on the threat of exotic arthropods and arthropod-borne pathogens to livestock in the United States, Anim. Biodiv. Emerg. Dis. (2008) 1149:249-254.

[31] Gibbs E.P., Greiner E.C., The epidemiology of bluetongue, Comp. Immunol. Microbiol. Infect. Dis. (1994) 17:207-220.

[32] Gloster J., Burgin L., Witham C., Athanassiadou M., Mellor P.S., Bluetongue in the United Kingdom and northern Europe in 2007 and key issues for 2008, Vet. Rec. (2008) 162:298-302.

[33] Gould A.R., Hyatt A.D., The Orbivirus genus. Diversity, structure, replication and phylogenetic relationships, Comp. Immunol. Microbiol. Infect. Dis. (1994) 17:163-188.

[34] Gould E.A., Higgs S., Buckley A., Gritsun T.S., Potential Arbovirus emergence and implications for the United Kingdom, Emerg. Infect. Dis. (2006) 12:549-555.

[35] Gould E.A., Higgs S., Impact of climate change and other factors on emerging Arbovirus diseases, Trans. R. Soc. Trop. Med. Hyg. (2009) 103:109-121.
[36] Guthrie A.J., African horse sickness, in: Sellon D.C., Long M.T. (Eds.), Equine infectious diseases, Saunders Elsevier, St. Louis, 2007, pp. 164-171.

[37] Guthrie A.J., Quan M., African horse sickness, Equine Vet. Edu. (2009) Manual 8:120-128.

[38] Guthrie A.J., Pardini A.D., Howell P.G., Equine encephalosis, Equine Vet. Edu. (2009) Manual 8: 145-150.

[39] Haig D.A., McIntosh B.M., Cumming R.B., Hempstead J.F.D., An outbreak of horsesickness, complicated by distemper in a pack of foxhounds, J. S. Afr. Vet. Med. Assoc. (1956) 27:245-249.

[40] Hazrati A., Identification and typing of horsesickness virus strains isolated in the recent epizootic of the disease in Morocco, Tunisia and Algeria, Arch. Inst. Razi (1967) 19:131-143.

[41] Henning M.W., African horsesickness, perdesiekte, pestis equorum, Animal diseases of South Africa, 3rd ed., Central News Agency Ltd., Pretoria, 1956, pp. 785-808.

[42] Hoffmann B., Beer M., Reid S.M., Mertens P., Oura C.A., Van Rijn P.A., et al., A review of RT-PCR technologies used in veterinary virology and disease control: sensitive and specific diagnosis of five livestock diseases notifiable to the World Organisation for Animal Health, Vet. Microbiol. (2009) 139:1-23.

[43] Hofmann M.A., Renzullo S., Mader M., Chaignat V., Worwa G., Thuer B., Genetic characterization of Toggenburg Orbivirus, a new bluetongue virus, from goats, Switzerland, Emerg. Infect. Dis. (2008) 14:1855-1861.

[44] Howell P.G., The 1960 epizootic of African horsesickness in the Middle East and S.W. Asia, J. S. Afr. Vet. Med. Assoc. (1960) 31:329-334.

[45] Howell P.G., The isolation and identification of further antigenic types of African horsesickness virus, Onderstepoort J. Vet. Res. (1962) 29:139-149.

[46] Howell P.G., Emerging diseases of animals. II. African horsesickness, FAO Agric. Stud. (1963) 61:71-108.

[47] Howell P.G., Groenewald D., Visage C.W., Bosman A.M., Coetzer J.A.W., Guthrie A.J., The classification of seven serotypes of equine encephalosis virus and the prevalence of homologous antibody in horses in South Africa, Onderstepoort J. Vet. Res. (2002) 69:79-93.

[48] Howell P.G., Guthrie A.J., Coetzer J.A.W., Equine encephalosis, in: Coetzer J.A.W., Tustin R.C. (Eds.), Infectious diseases of livestock, 2nd ed., Oxford University Press Southern Africa, Cape Town, 2004, pp. 1247-1251.

[49] Howell P.G., Nurton J.P., Nel D., Lourens C.W., Guthrie A.J., Prevalence of serotype specific antibody 
to equine encephalosis virus in Thoroughbred yearlings in South Africa (1999-2004), Onderstepoort J. Vet. Res. (2008) 75:153-161.

[50] Jauniaux T.P., De Clercq K.E., Cassart D.E., Kennedy S., Vandenbussche F.E., Vandemeulebroucke E.L., et al., Bluetongue in Eurasian lynx, Emerg. Infect. Dis. (2008) 14:1496-1498.

[51] Kitano Y., Ibaraki disease in cattle, in: Coetzer J.A.W., Tustin R.C. (Eds.), Infectious diseases of livestock, 2nd ed., Oxford University Press Southern Africa, Cape Town, 2004, pp. 1221-1226.

[52] Lubroth J., African horsesickness and the epizootic in Spain 1987, Equine Pract. (1988) 10:26-33.

[53] MacDonald N.E., West Nile virus in the context of climate change, Can. J. Infect. Dis. Med. Microbiol. (2008) 19:217-218.

[54] MacLachlan N.J., Osburn B.I., Epizootic hemorrhagic disease of deer, in: Coetzer J.A.W., Tustin R.C. (Eds.), Infectious diseases of livestock, 2nd ed., Oxford University Press Southern Africa, Cape Town, 2004, pp. 1227-1230.

[55] MacLachlan N.J., Osburn B.I., Impact of bluetongue virus infection on the international movement and trade of ruminants, J. Am. Vet. Med. Assoc. (2006) 228:1346-1349.

[56] MacLachlan N.J., Dubovi E., Veterinary and zoonotic virology, 4th ed., Elsevier, 2010.

[57] MacLachlan N.J., Drew C.P., Darpel K.E., Worwa G., The pathology and pathogenesis of bluetongue, J. Comp. Pathol. (2009) 141:1-16.

[58] MacLachlan N.J., Global implications of the recent emergence of bluetongue in Europe, Vet. Clin. North Am. (2010) 26:163-171.

[59] Mauroy A., Guyot H., De Clercq K., Cassart D.E., Thiry E., Saegerman C., Bluetongue in captive yaks, Emerg. Infect. Dis. (2008) 14:675-676.

[60] McIntosh B.M., Horsesickness antibodies in the sera of dogs in enzootic areas, J. S. Afr. Vet. Med. Assoc. (1955) 26:269-272.

[61] McIntosh B.M., Immunological types of horsesickness virus and their significance in immunization, Onderstepoort J. Vet. Res. (1958) 27:465-539.

[62] Meiswinkel R., Baylis M., Labuschagne K., Stabling and the protection of horses from Culicoides bolitinos (Diptera: Ceratopogonidae), a recently identified vector of African horse sickness, Bull. Entomol. Res. (2000) 90:509-515.

[63] Mertens P.P., Diprose J., Maan S., Singh K.P., Attoui H., Samuel A., Bluetongue virus replication, molecular and structural biology, Vet. Ital. (2004) 40:426-437.
[64] Mildenberg Z., Westcott D., Bellaiche M., Dastjerdi A., Steinbach F., Drew T., Equine encephalosis virus in Israel, Transbound. Emerg. Dis. (2009) 56:291.

[65] Petersen L.R., Hayes E.B., West Nile virus in the Americas, Med. Clin. North Am. (2008) 92:13071322.

[66] Pialoux G., Gauzere B.A., Jaureguiberry S., Strobel M., Chikungunya, an epidemic arbovirosis, Lancet Infect. Dis. (2007) 7:319-327.

[67] Piercy S.E., Some observations on African horse-sickness including an account of an outbreak among dogs, East Afr. Agric. J. (1951) 17:62-64.

[68] Pinto J., Bonacic C., Hamilton-West C., Romero J., Lubroth J., Climate change and animal diseases in South America, Rev. Sci. Tech. (2008) 27:599-613.

[69] Purse B.V., Mellor P.S., Rogers D.J., Samuel A.R., Mertens P.P., Baylis M., Climate change and the recent emergence of bluetongue in Europe, Nat. Rev. Microbiol. (2005) 3:171-181.

[70] Purse B.V., Brown H.E., Harrup L., Mertens P.P.C., Rogers D.J., Invasion of bluetongue and other Orbivirus infections into Europe: the role of biological and climatic processes, Rev. Sci. Tech. (2008) 27: $427-442$.

[71] Quan M., van Vuuren M., Howell P.G., Groenewald D., Guthrie A.J., Molecular epidemiology of the African horse sickness virus S10 gene, J. Gen. Virol. (2008) 89:1159-1168.

[72] Reid N.R., African horse sickness, Br. Vet. J. (1961) 118:137-142.

[73] Rodriguez M., Hooghuis H., Castano M., African horse sickness in Spain, Vet. Microbiol. (1992) 33:129-142.

[74] Rogers D.J., Randolph S.E., Climate change and vector-borne diseases, Adv. Parasitol. (2006) 62: 345-381.

[75] Russell R.C., Currie B.J., Lindsay M.D., Mackenzie J.S., Ritchie S.A., Whelan P.I., Dengue and climate change in Australia: predictions for the future should incorporate knowledge from the past, Med. J. Aust. (2009) 190:265-268.

[76] Sailleau C., Seignot J., Davoust B., Cardinale E., Fall B., Hamblin C., Zientara S., African horse sickness in Senegal: serotype identification and nucleotide sequence determination of segment S10 by RT-PCR, Vet. Rec. (2000) 146:107-108.

[77] Schwartz-Cornil I., Mertens P.P., Contreras V., Hemati B., Pascale F., Bréard E., et al., Bluetongue virus: virology, pathogenesis and immunity, Vet. Res. (2008) 39:46. 
[78] Sellers R.F., Pedgley D.E., Tucker M.R., Possible spread of African horse sickness on the wind, J. Hyg. (1977) 79:279-298.

[79] Tabachnick W.J., Culicoides and the global epidemiology of bluetongue virus infection, Vet. Ital. (2004) 40:145-150.

[80] Theiler A., Transmission of horse sickness into dogs, Rep. Govern. Vet. Bacteriol. (1906) 160-162.

[81] Theiler A., Notes on a fever in horses simulating horse-sickness, Transvaal. Agric. J. (1910) 8:581-586.

[82] Theiler A., African horse sickness (pestis equorum), Sci. Bull. (1921) 19:1-29.

[83] Thom H.B., Journal of Jan van Riebeeck, A.A. Balkema, Cape Town/Amsterdam, 1952.

[84] Verwoerd D.W., Erasmus B.J., Bluetongue, in: Coetzer J.A.W., Tustin R.C. (Eds.), Infectious diseases of livestock, 2nd ed., Oxford University Press Southern Africa, Cape Town, 2004, pp. 1201-1220.

[85] Weaver S.C., Reisen W.K., Present and future arboviral threats, Antiviral Res. (2009) 85:328-345.

[86] Wilson A.J., Mellor P.S., Bluetongue in Europe: past, present and future, Philos. Trans. R. Soc. Lond. B Biol. Sci. (2009) 364:2669-2681.
[87] Wouda W., Roumen M.P., Peperkamp N.H., Vos J.H., van Garderen E., Muskens J., Hydranencephaly in calves following the bluetongue serotype 8 epidemic in the Netherlands, Vet. Rec. (2008) 162: 422-423.

[88] Wouda W., Peperkamp N.H., Roumen M.P., Muskens J., van Rijn A., Vellema P., Epizootic congenital hydranencephaly and abortion in cattle due to bluetongue virus serotype 8 in the Netherlands, Tijdschr. Diergeneeskd. (2009) 134:422-427.

[89] Yadin H., Brenner J., Brumbrov V., Oved Z., Stram Y., Klement E., et al., Epizootic haemorrhagic disease virus type 7 infection in cattle in Israel, Vet. Rec. (2008) 162:53-56.

[90] Zeleke A., Sori T., Powel K., Gebre-Ab F., Endebu B., Isolation and identification of circulating serotypes of African horse sickness virus in Ethiopia, Intern. J. Appl. Res. Vet. Med. (2005) 3:40-43.

[91] Zell R., Krumbholz A., Wutzler P., Impact of global warming on viral diseases: what is the evidence?, Curr. Opin. Biotechnol. (2008) 19:652-660.

[92] Zientara S., Sailleau C., Plateau E., Moulay S., Mertens P.P., Cruciere C., Molecular epidemiology of African horse sickness virus based on analyses and comparisons of genome segments 7 and 10, Arch. Virol. Suppl. (1998) 14:221-234. 